\title{
Antimicrobial Activity of Bacteriocins Isolated from Lactic Acid Bacteria Against Resistant Pathogenic Strains
}

\author{
Muhammad Zahid", ", Muhammad Ashraf ${ }^{1}$, Muhammad Arshad ${ }^{1}$, Ghulam Muhammad ${ }^{2}$, \\ Aqeela Yasmin ${ }^{1}$, Hafiz Muhammad Adnan Hameed ${ }^{3}$ \\ ${ }^{1}$ Institute of Microbiology/University of Agriculture, Faculty of Veterinary Science, Faisalabad, Pakistan \\ ${ }^{2}$ Department of Clinical Medicine and Surgery /University of Agriculture, Faisalabad, Pakistan \\ ${ }^{3}$ Centre of Agricultural Biochemistry and Biotechnology (CABB), University of Agriculture, Faisalabad, Pakistan \\ Email address: \\ mzahidkakkar@gmail.com (M. Zahid),mashraf@uaf.edu.pk (M. Ashraf),drarshaduaf@gmail.com (M. Arshad), \\ profdrgm54@gmail.com (G. Muhammad),draqeela@ymail.com (A. Yasmin), edensettler@gmail.com (H. M. A. Hamid)
}

\section{To cite this article:}

Muhammad Zahid, Muhammad Ashraf, Muhammad Arshad, Ghulam Muhammad, Aqeela Yasmin, Hafiz Muhammad Adnan Hameed. Antimicrobial Activity of Bacteriocins Isolated from Lactic Acid Bacteria Against Resistant Pathogenic Strains. International Journal of Nutrition and Food Sciences. Vol. 4, No. 3, 2015, pp. 326-331. doi: 10.11648/j.ijnfs.20150403.20

\begin{abstract}
This study was carried out to treat the microbial diseases in natural way and reduced the antibiotic resistance pressure. Five species of Lactic acid bacteria namely, L. acidophilus, L. bulgaricus, L. dulbrueckii L. plantarum, and L. fermentum, were isolated from locally produced yogurt. Bacteriocins were isolated from MRS broth culture of theses Lactic acid bacteria through the ammonium sulphate precipitation method. Extracted bacteriocins were tested against test strain i.e E.coli ATCC 25922 to obtain optimum $\mathrm{pH}$, storage temperature and heating temperature for maximum antibacterial activity. For this (2-12) $\mathrm{pH}$ range, storage temperatures $\left(-20{ }^{\circ} \mathrm{C}, 4{ }^{\circ} \mathrm{C}\right.$ and $37{ }^{\circ} \mathrm{C}$ for 1 month) and heating temperatures $\left(60{ }^{\circ} \mathrm{C}, 100{ }^{\circ} \mathrm{C}\right.$ and $121{ }^{\circ} \mathrm{C}$ for 15 minutes $)$ were tested. Later the antibacterial activity of these bacteriocins were tested at concluded optimum conditions against each other as well as against different locally isolated pathogens viz. Methicillin-Resistant-Staphylococcus-aureus, E.coli, Salmonella and Staphylococcus aureus by using well diffusion agar method. It was found that bacteriocins activities were maximum at $\mathrm{pH} 6$ and $4{ }^{\circ} \mathrm{C}$ storage temperature. Maximum activity was found after heating bacteriocins at $60{ }^{\circ} \mathrm{C}$ as compared to $100{ }^{\circ} \mathrm{C}$ and $121{ }^{\circ} \mathrm{C}$. Bacteriocins of lactobacilli were harmless against each other at any $\mathrm{pH}$, heat temperatures and storage temperatures. Antibacterial activity of bacteriocins extracted from L.acidophilus showed maximum activity against pathogenic bacteria as compare to others. The present study has highlighted the antibacterial role of bacteriocins isolated from Lactic acid bacteria by indicating their potential to treat a variety of human and animal diseases.
\end{abstract}

Keywords: Lactic Acid Bacteria (LAB), Antibiotic Resistant Pathogens, Optimum pH, Heat and Storage Temperature

\section{Introduction}

Continuously increasing level of resistance against antibiotics is the highlight aspect of 21 st century [1]. Microbial diseases have been treated with antibiotics just after their introduction. Since then, antibiotic resistance is the problem and threat in the successful antibiotic treatment of bacterial infections [2].

Microbes become antibiotic resistant due to partial exposure to one or more antibiotics. Incomplete therapy, gene mutations as well as vertical and horizontal gene transfer among bacteria are also important factors for the development of resistance. [2,3]
Choice of antibiotics against multi drug resistant (MDR) bacteria is limiting continuously so the discovery of new antimicrobial tools or antibiotics is the solution of this problem [4]

Antagonist microbial interference has been reported from last century of microbiology [5]. This cross interference has become more valuable and alternative method to treat and kill the pathogens [6].

Bacteriocins producing Lactic acid bacteria are the best alternatives to conventional antibiotics [7]. So lactic acid bacteria (LAB) are helpful in treatment without raising the antibiotic resistance level [6]. Lactic acid bacteria are capable to generate diverse antimicrobial 
composites in the course of lactic acid fermentation as bacteriocins, hydrogen peroxide $\left(\mathrm{H}_{2} \mathrm{O}_{2}\right)$, organic acids and diacetyl, [8]. Bacteriocins are helpful in treatment without raising the antibiotic resistance level [6].

Bacteriocins are released extracellular low weight peptides that may be bacteriostatic but surely bactericidal [9]. Primary tool of lactobacilli to kill the pathogens is the reduction of $\mathrm{pH}$ through the production of lactic acid [10].

Bacteriocins are actually ribosomally synthesized peptides, consisting of 30-60 amino acids and they show effective antimicrobial activity against certain other pathogens [11]. These bacteriocins are harmless against its own producers because the secretory bacterial strains have genetically pre determined genes of immunity $[12,13]$

Bacteriocins of Clostridia, Staphylococcal and Lactobacillus may be the combination of carbohydrate, lipid and protein or purely proteinaceous. Beneficially protenatious bacteriocins are easily get digested in human gastrointestinal (GI) tract [13].

This strategy has been evaluated by many researchers. The production of bacteriocins up to 10-100 different types has been reported even by a single species. So this diversityof bacteriocins have made them best candidate as an alternative to conventional antibiotics [14,15]

Lactobacilli belong to lactic acid bacteria and are generally recognized as safe (GRAS) because they are the habitant of normal microflora of Gastric Intestinal (GI) tract. Some members of LAB are considered as probiotics [16,17]. Lactobacilli are being used frequently as probiotics among Enterococcus, Bifidobacterium, Bacillus, as well as Saccharomyces strains $[18,19]$. So now a day's probiotics are medically great important, in the treatment of infections and their control [20].

Probiotics have valuable contribution in physiology and in the maintenance of fitness of human beings. So they have high rank for their use in such practices that are being carried out to get benefits of livestock and human. Probiotics have antimicrobial substances and bacteriocins like lethal tools for different pathogens that help in maintaining the fitness of human beings without using antibiotics. Treatment through this substitutional technique is being practices on large scale [12,21].

The aim of study was extraction of bacteriocins from Lactic acid bacteria isolated from locally produced yogurt and determination of antibacterial effect of bacteriocins against different antibiotic resistant pathogenic bacterial strains.

\section{Materials and Methods}

\subsection{Collection and Isolation of Lactic Acid Bacteria from Yogurt}

30 yogurt samples collected from the local market of Faisalabad were spreaded on de Man Rogosa Sharp (MRS) agar medium and incubated at $37^{\circ} \mathrm{C}$ for $24-48$ hours anaerobically. The isolated organisms from the sample were screened on the basis of their morphological and biochemical characteristics as described in Bergey's Manual of systematic bacteriology [22].

\subsection{Extraction of Bacteriocins}

Cell free supernatants of Lactic acid bacteria were obtained after centrifugation at $7100 \mathrm{rpm}$ for $15 \mathrm{~min}$ at $12{ }^{\circ} \mathrm{C}$. Cell free supernatant was heated at $90{ }^{\circ} \mathrm{C}$ for 12 minutes. The obtained cell free supernatant was then precipitated with $40 \%$ solution of ammonium sulphate. The mixture was stirred for 24 hours at $12{ }^{\circ} \mathrm{C}$ and then centrifuged at $10000 \mathrm{rpm}$ for 20 minutes at $7{ }^{\circ} \mathrm{C}$. The pellets were collected in Tris-buffer having $7 \mathrm{pH}[23,24]$.

\subsection{Confirmation of Bacteriocin}

Bacteriocin was confirmed through proteolytic enzymes i.e protease, proteinase $\mathrm{K}$, and trypsin with concentration $0.25 \mathrm{mg} \mathrm{mL}-1$.

\subsection{Stability of Isolated Bacteriocins}

Stability as well as antimicrobial potential of isolated bacteriocins were checked at (2-12) $\mathrm{pH}$ range, at different heat temperatures $\left(60{ }^{\circ} \mathrm{C}, 100{ }^{\circ} \mathrm{C}\right.$ and $121{ }^{\circ} \mathrm{C}$ for $\left.15 \mathrm{~min}\right)$ and at different storage temperatures $\left(-20{ }^{\circ} \mathrm{C}, 4{ }^{\circ} \mathrm{C}\right.$ and $\left.37^{\circ} \mathrm{C}\right)$.

\subsection{Cross Sensitivity}

All the bacteriocins producing isolates were challenged against each other to check the cross sensitivity.

\subsection{Pathogenic Bacterial Strains}

The cultures of pathogenic strains (Methicillin-ResistantStaphylococcus-aureus, E.coli, Salmonella, Staphylococcus aureus) were obtained from stock culture of the Department of Clinical, Medicine and surgery, Agriculture University, Faisalabad. Cultures used in this study were transferred twice in to the blood agar medium before use.

\subsection{Determination of Antimicrobial Activity}

The antimicrobial activity was checked by the well diffusion assay [25]. Aliqout of $50 \mu \mathrm{l}$ from each extract were added to the well of size $6 \mathrm{~mm}$. Then indicator strains of bacteria $\left(5 \times 10^{8} \mathrm{CFU} / \mathrm{ml}\right)$ were spread on Mueller-Hinton agar $(\mathrm{MH})$ plates. Plates were incubated at $37{ }^{\circ} \mathrm{C}$ for $24 \mathrm{hrs}$ to check pathogenic indicator bacterial growth. The diameters of the zones of inhibition were measured as recommended by [26].

\subsection{Statistical Anaylsis}

Data were analyzed by applying Standard Error (Mean \pm SE) and anaylsis of variance (ANOVA) under completely randomized design. Mean of triplet values having $\mathrm{p}<0.05$ are significant. 


\section{Results}

Isolated colonies of Lactic acid bacteria appeared on MRS agar were circular, convex, smooth and white to creamy. Isolates were Gram positive, acid fast negative, catalase negative, indole negative and oxidase negative. These isolates were identified as L. acidophilus, $L$. bulgaricus and L. dulbrueckii on the basis of sugar fermentation tests [23,27].

In this study bacteriocins were subjected to different $\mathrm{pH}$ conditions against test strain i.e E.coli ATCC 25922 and the results obtained showed that maximum activity of bacteriocins were at $\mathrm{pH} 6$. The activity was lower at $\mathrm{pH} 4$ while the activity was even more reduced at $\mathrm{pH} 8$. There was no significant activity at $\mathrm{pH} 2,10$ and 12 (Table 2).

Different heating temperatures i.e. $60{ }^{\circ} \mathrm{C}, 100{ }^{\circ} \mathrm{C}$ and $121{ }^{\circ} \mathrm{C}$ were employed for $15 \mathrm{~min}$ to detect the stability of bacteriocins at these temperatures against test strain i.e E.coli ATCC 25922. At $60{ }^{\circ} \mathrm{C}$ significant activity was obtained but this activity was lower as compared to activity of bacteriocins at normal room temperature. The bacteriocin extracted from L.acidophilus showed higher stability as compared to bacteriocins extracted from other lactobacilli. Non significant activity was detected at $100{ }^{\circ} \mathrm{C}$ and $121{ }^{\circ} \mathrm{C}$ among all lactobacilli bacteriocins except bacteriocin of L. acidophilus (Table 3 ).

Different storage temperatures were evaluated to conclude best storage temperature suitable for bacteriocins. The overall activity of bacteriocins after storing them at $4{ }^{\circ} \mathrm{C}$ for 30 days was maximum against test strain i.e E.coli ATCC 25922 but slightly reduced when bacteriocins were stored at $-20{ }^{\circ} \mathrm{C}$ and $37{ }^{\circ} \mathrm{C}$. No significant change in activity was observed in case of L.acidophilus at any storage temperature (Table 4).

Different pre-isolated pathogens were used to determine the activity of different bacteriocins extracted from different lactobacilli species. Antimicrobial activity of bacteriocins were observed at $6 \mathrm{pH}, 60{ }^{\circ} \mathrm{C}$ heat temperature and $4{ }^{\circ} \mathrm{C}$ storage temperature where its activity was maximum against test strain. L.acidophilus showed highly significant activity against MRSA, Staphylococcus aureus and E.coli while non-significant activity was observed against Salmonella typhi. Nonsignificant activity was observed in rest of bacteriocins against all pathogens (Table 5).

Table 1. Pathogenic bacteria resistant against couple of antibiotics.

\begin{tabular}{ll}
\hline Pathogens & Resistant againt antibiotics \\
\hline Methicillin-Resistant-Staphylococcus-aureus & Methicillin, Amoxicillin-clavulanic acid, Amoxicillin, Ampicillin \\
E.coli & Amoxicillin-clavulanic acid, Ceftriaxone, Ceftazidime \\
Salmonella & Ceftazidime, Amoxicillin-clavulanic acid \\
Staphylococcus aureus & Amoxicillin, Ampicillin \\
\hline
\end{tabular}

Table 2. Zones of inhibition of LAB at different pH against E.coli ATCC 25922.

\begin{tabular}{|c|c|c|c|c|c|c|}
\hline \multirow{2}{*}{ pH level } & \multicolumn{5}{|c|}{ Bacteriocin of differents LAB } & \multirow{2}{*}{ Mean } \\
\hline & L. acidophilus & L.bulgaricus & L. delbruckeii & L. fermentum & L.plantarum & \\
\hline 2 & $10 \pm 0.58 \mathrm{~cd}$ & $0 \pm 0.00 \mathrm{f}$ & $0 \pm 0.00 \mathrm{f}$ & $0 \pm 0.00 \mathrm{f}$ & $0 \pm 0.00 \mathrm{f}$ & $2 \pm 1.07 \mathrm{E}$ \\
\hline 4 & $19 \pm 1.15 b$ & $9 \pm 0.58 \mathrm{cde}$ & $9 \pm 0.58 \mathrm{cde}$ & $8 \pm 0.58 \mathrm{de}$ & $9 \pm 0.58 \mathrm{cde}$ & $10.8 \pm 1.13 \mathrm{~B}$ \\
\hline 6 & $26 \pm 0.58 \mathrm{a}$ & $9 \pm 0.58 \mathrm{cde}$ & $10 \pm 0.58 \mathrm{~cd}$ & $9 \pm 0.58 \mathrm{cde}$ & $9 \pm 0.58 \mathrm{cde}$ & $12.6 \pm 1.81 \mathrm{~A}$ \\
\hline 8 & $27 \pm 1.00 \mathrm{a}$ & $8 \pm 0.58 \mathrm{de}$ & $7 \pm 1.15 \mathrm{de}$ & $0 \pm 0.00 \mathrm{f}$ & $0 \pm 0.00 \mathrm{f}$ & $8.4 \pm 2.66 \mathrm{C}$ \\
\hline 10 & $18 \pm 1.73 b$ & $0 \pm 0.00 \mathrm{f}$ & $0 \pm 0.00 \mathrm{f}$ & $0 \pm 0.00 \mathrm{f}$ & $6 \pm 1.15 \mathrm{e}$ & $4.8 \pm 1.90 \mathrm{D}$ \\
\hline 12 & $12 \pm 0.58 \mathrm{c}$ & $0 \pm 0.00 \mathrm{f}$ & $0 \pm 0.00 \mathrm{f}$ & $0 \pm 0.00 \mathrm{f}$ & $0 \pm 0.00 \mathrm{f}$ & $2.4 \pm 1.29 \mathrm{E}$ \\
\hline Mean & $18.67 \pm 1.58 \mathrm{~A}$ & $4.33 \pm 1.06 \mathrm{~B}$ & $4.33 \pm 1.09 \mathrm{~B}$ & $2.83 \pm 0.98 \mathrm{C}$ & $4 \pm 1.02 \mathrm{~B}$ & \\
\hline
\end{tabular}

Means sharing similar letter in a row or in a column are statistically non-significant $(\mathrm{P}>0.05)$. Small letters represent comparison among interaction means and capital letters are used for overall mean.

Table 3. Zones of inhibition of LAB after different heat treatments against E.coli ATCC 25922.

\begin{tabular}{|c|c|c|c|c|c|c|}
\hline \multirow{2}{*}{ Heat Temp } & \multicolumn{5}{|c|}{ Bacteriocin of differents LAB } & \multirow{2}{*}{ Mean } \\
\hline & L. acidophilus & L.bulgaricus & L. delbruckeii & L. fermentum & L.plantarum & \\
\hline $60{ }^{\circ} \mathrm{C}$ & $24 \pm 2.31 \mathrm{a}$ & $9 \pm 0.58 b$ & $9 \pm 0.58 b$ & $9 \pm 0.58 b$ & $9.00 \pm 1.00 \mathrm{~b}$ & $12.00 \pm 1.67 \mathrm{~A}$ \\
\hline $100^{\circ} \mathrm{C}$ & $20 \pm 1.00 \mathrm{a}$ & $7 \pm 1.15 b$ & $6 \pm 1.15 b$ & $0 \pm 0.00 \mathrm{c}$ & $0.00 \pm 0.00 \mathrm{c}$ & $6.60 \pm 1.98 \mathrm{~B}$ \\
\hline $121^{\circ} \mathrm{C}$ & $20 \pm 0.58 \mathrm{a}$ & $0 \pm 0.00 \mathrm{c}$ & $0 \pm 0.00 \mathrm{c}$ & $0 \pm 0.00 \mathrm{c}$ & $0.00 \pm 0.00 \mathrm{c}$ & $4.00 \pm 2.14 \mathrm{C}$ \\
\hline Mean & $21.33 \pm 1.00 \mathrm{~A}$ & $5.33 \pm 1.41 \mathrm{~B}$ & $5 \pm 1.37 \mathrm{BC}$ & $3 \pm 1.51 \mathrm{C}$ & $3.00 \pm 1.53 \mathrm{C}$ & \\
\hline
\end{tabular}

Means sharing similar letter in a row or in a column are statistically non-significant $(\mathrm{P}>0.05)$. Small letters represent comparison among interaction means and capital letters are used for overall mean. 
Table 4. Zones of inhibition of LAB after storaging at different temperatures against E.coli ATCC 25922.

\begin{tabular}{lllllll}
\hline \multirow{2}{*}{ Storage Temp } & \multicolumn{2}{l}{ Bacteriocin of differents LAB } & & \\
\cline { 2 - 7 } & L. acidophilus & L.bulgaricus & L. delbruckeii & L. fermentum & L.plantarum & \\
\hline$-20{ }^{\circ} \mathrm{C}$ & $26.00 \pm 1.00 \mathrm{a}$ & $7.00 \pm 1.15 \mathrm{~b}$ & $7.00 \pm 1.15 \mathrm{~b}$ & $10.00 \pm 0.58 \mathrm{~b}$ & $7.00 \pm 0.58 \mathrm{~b}$ & $11.40 \pm 2.01 \mathrm{~B}$ \\
$4{ }^{\circ} \mathrm{C}$ & $25.00 \pm 0.58 \mathrm{a}$ & $10.00 \pm 0.58 \mathrm{~b}$ & $9.00 \pm 0.58 \mathrm{~b}$ & $8.00 \pm 0.58 \mathrm{~b}$ & $11.00 \pm 1.15 \mathrm{~b}$ & $12.60 \pm 1.70 \mathrm{~A}$ \\
$37{ }^{\circ} \mathrm{C}$ & $26.00 \pm 1.15 \mathrm{a}$ & $8.00 \pm 0.58 \mathrm{~b}$ & $8.00 \pm 0.58 \mathrm{~b}$ & $7.00 \pm 1.15 \mathrm{~b}$ & $8.00 \pm 0.58 \mathrm{~b}$ & $11.40 \pm 1.98 \mathrm{~B}$ \\
Mean & $25.67 \pm 0.50 \mathrm{~A}$ & $8.33 \pm 0.60 \mathrm{~B}$ & $8.00 \pm 0.50 \mathrm{~B}$ & $8.33 \pm 0.60 \mathrm{~B}$ & $8.67 \pm 0.73 \mathrm{~B}$ & \\
\hline
\end{tabular}

Means sharing similar letter in a row or in a column are statistically non-significant $(\mathrm{P}>0.05)$. Small letters represent comparison among interaction means and capital letters are used for overall mean.

\section{Discussion}

Considering the pace of bacteria to become multi-drug resistant there is a need of some alternative techniques for their treatment. The purpose of this study was to isolate the bacteriocin producing Lactic acid bacteria for the cure and treatment of bacterial infectious diseases. Many researchers have highlighted the lactic acid bacteria as best alternative to antibiotics and recommended them for therapeutic use due to their antimicrobial ability $[23,28])$. Lactic acid bacteria were isolated from locally produced yogurt as it was reported that these bacteria are inhabitant of milk and milk products $[29,30]$.

Bacteriocins were isolated from cell free supernatant of LAB in MRS broth through ammonium sulphate precipitation method. Garneau et al., (2002) also preferred this technique on the basis of short time and bacteriocin quantity [11]. Bacteriocin is an antimicrobial proteinaceous secretion of lactic acid bacteria. Abada (2008) documented that most of the bacteriocins are purely build up with peptides as well as some are the compositions of protein, carbohydrates and lipids [12].

Lactic acid bacteria can inhibit the antibiotic resistant bacterial growth through the secretion of bacteriocin, hydrogen peroxide $\left(\mathrm{H}_{2} \mathrm{O}_{2}\right)$, organic acids and diacetyl [31,32]. To confirm that antimicrobial agent is extracted bacteriocin it was treated with some proteolytic enzymes. There were no zones of inhibition by bacteriocin after dealing it with proteolytic enzymes. That indicated its proteinaceous nature along with proofing it as antimicrobial agent. Same methodology was chosen by some scientists to confirm its proteinaceous nature and their results were parallel to our results [34].

Inhibitory activity against antibiotic resistant bacteria was checked through agar well diffusion method and zone of inhibition were measured .The diameter of zone of inhibitions against pathogenic bacteria were different. Schved et al., (1993) described that zone of inhibitions can describe the degree of sensitivity and resistance of bacteria [34].

After study it was concluded that bacteriocin of lactobacilli showed antimicrobial activity against E.coli ATCC 25922 in 4-8 pH range. Most of lactobacilli showed non-significant activity at 2,10 and $12 \mathrm{pH}$ except lactobacillus acidophilus (Table 2). Gerez et al., (2009) and Todorov et al., (2006) documented that bacteriocins performed well in killing as well as limiting the growth of pathogens in acidic $\mathrm{pH}$ as compare to basic $\mathrm{pH}[35,36]$.

Bacteriocins were more effective after heating at $60{ }^{\circ} \mathrm{C}$ for 15 minutes against E.coli ATCC 25922. Bacteriocin of few species showed positive activity even at $100{ }^{\circ} \mathrm{C}, 121$ ${ }^{\circ} \mathrm{C}$. Because bacteriocin is proteinaceous in nature so with the increase in temperature its effectiveness decrease but diminished except L.acidophilus (Table 3). Rowaida et al., (2009); Mojgani and Amirinia, (2007) recorded antimicrobial activity of bacteriocin at $121{ }^{\circ} \mathrm{C}$ that is in accordance to our results [37,38].

Storage temperature and duration affects the antimicrobial activity of bacteriocin. $4{ }^{\circ} \mathrm{C}$ temperature was found most suitable for the storage of bacteriocin because in our study maximum zones of inhibitions were obtained against E.coli ATCC 25922 after storing bacteriocin at this temperature. Bacteriocin were effective also at $-20{ }^{\circ} \mathrm{C}$ and $37{ }^{\circ} \mathrm{C}$ but the antimicrobial potential after storage at these temperatures were less than the antimicrobial potential after storage at $4{ }^{\circ} \mathrm{C}$ temperature (Table 4). Rowaida et al., (2009) ; Malini and Savitha, (2012) concluded after their study that cold temperature is more suit able for bacteriocin storage as compare to hot temperature. Storage at $-20{ }^{\circ} \mathrm{C}$ may reduce the potential due to crystallization of bacteriocin $[37,38]$.

Table 5. Zones of inhibition of LAB against different antibiotic resistant bacteria.

\begin{tabular}{lllllll}
\hline \multirow{2}{*}{ Antibiotic resistant bacteria } & \multicolumn{2}{l}{ Bacteriocin of differents LAB } & & \multirow{2}{*}{ Mean } \\
\cline { 2 - 6 } & L.acidophilus & L.bulgaricus & L.delbruckeii & L. fermentum & L.plantarum & \\
\hline MRSA & $23.00 \pm 1.15 \mathrm{a}$ & $11.00 \pm 1.15 \mathrm{~b}$ & $11.00 \pm 1.15 \mathrm{~b}$ & $8.00 \pm 0.58 \mathrm{~b}$ & $11.00 \pm 1.00 \mathrm{~b}$ & $12.80 \pm 1.45 \mathrm{~A}$ \\
Staphylo coccus & $24.00 \pm 2.31 \mathrm{a}$ & $10.00 \pm 0.58 \mathrm{~b}$ & $10.00 \pm 0.58 \mathrm{~b}$ & $8.00 \pm 0.58 \mathrm{~b}$ & $10.00 \pm 1.00 \mathrm{~b}$ & $12.40 \pm 1.63 \mathrm{~A}$ \\
E.coli & $27.00 \pm 1.00 \mathrm{a}$ & $9.00 \pm 0.58 \mathrm{~b}$ & $9.00 \pm 0.58 \mathrm{~b}$ & $9.00 \pm 0.58 \mathrm{~b}$ & $8.00 \pm 0.58 \mathrm{~b}$ & $12.60 \pm 1.94 \mathrm{~A}$ \\
Salmonella & $10.00 \pm 0.58 \mathrm{~b}$ & $8.00 \pm 0.58 \mathrm{~b}$ & $7.90 \pm 0.58 \mathrm{~b}$ & $9.00 \pm 0.58 \mathrm{~b}$ & $8.00 \pm 0.58 \mathrm{~b}$ & $8.40 \pm 0.31 \mathrm{~B}$ \\
Mean & $21.00 \pm 2.06 \mathrm{~A}$ & $9.50 \pm 0.47 \mathrm{~B}$ & $9.49 \pm 0.47 \mathrm{~B}$ & $8.25 \pm 0.25 \mathrm{~B}$ & $9.50 \pm 0.48 \mathrm{~B}$ & \\
\hline
\end{tabular}

Means sharing similar letter in a row or in a column are statistically non-significant $(\mathrm{P}>0.05)$. Small letters represent comparison among interaction means and capital letters are used for overall mean. 
Antimicrobial activity of bacteriocin was checked in its optimum conditions ( $\mathrm{pH} 6$, heating at $60{ }^{\circ} \mathrm{C}$ for 15 minutes and storage at $4{ }^{\circ} \mathrm{C}$ for 30 days) against couple of antibiotic resistant bacteria. L.acidophilus found as most effective against all antibiotic resistant bacteria. Over all antimicrobial activity of all lactobacilli species were significant against MRS, Staphylococcus and E.coli. Results of extracted bacteriocins against Salmonella were non-significant (Table 5). Many scientists as Malini and Savitha, (2012); Hermine et al., (2010) recommended the $\mathrm{LAB}$ as best option to treat and kill resistant bacteria $[33,4]$.

Inhibitory activity of lactic acid bacteria was checked against each other but there were no zones of inhibitions. This is due the presence of the pre-determined immunity genes against their own bacteriocin so producers are harmless against their own bacteriocin $[39,40]$.

Conclusion of this study is that bacteriocins extracted from lactic acid bacteria have the potential to inhibit the growth of many antibiotic resistant bacteria including Methicillin resistant staphylococcus aureus, E.coli and staphylococcus aureus. So we can use them as an alternative therapeutic agent with no risk of antibiotic resistance as well as their use in the form of probiotic can reduce the risk of different infections.

\section{References}

[1] Michel M, Gutmann L (1997) Methicillin-resistant Staphylococcus aureus and vancomycin-resistant enterococci, therapeutic realities and possibilities, J. The Lancet., 349: $1901-1906$.

[2] Levy SB, (1997) Antibiotic resistance: An ecological imbalance. In Antibiotic Resistance: Origins, Evolution, Selection and Spread edited by DJ Chadwick, J Goode. Wiley, Chichester (Ciba Foundation Symposium 207) West Sussex, England. pp. 1-14. (ISBN 047197105 7).

[3] Salyers AA (1995) Antibiotic Resistance Transfer in the Mammalian Intestinal Tract: Implications for Human Health. Food Safety and Biotechnol. Springer-Verlag., S93-S106.

[4] Hermine M, Gibbons S, Heidelberger S, Zlohb M, and Limaki, KH (2010) Purification, characterisation and identification of acidocin LCHV, an antimicrobial peptide produced by Lactobacillus acidophilusn.v.Er 317/402 strain Narine. Int. J. Antimicrobial Agents, 35: 255-260.

[5] Jay JM, (1996) Microorganisms in fresh ground meats: The relative safety of products with low versus high numbers, $J$. Meat Sci., 43: S59-S65.

[6] Stiles M,E, (1996) Biopreservation by lactic acid bacteria, Antonie van Leuwenhoek, 70: 331-345.

[7] Gillor O, and Ghazaryan L (2007) Recent advances in bacteriocin application as antimicrobials, Recent Pattient on Anti-infective Drug Discovery, J. BSP., 2: 115-122.
[8] Oyetayo VO, Adetuyi FC, and Akinyosoye FA (2003) Safety and protective effect of Lactobacillus acidophilus and Lactobacillus casei used as probiotic agent in vivo, Afr. $J$. Biotechnol. 2: 448-452.

[9] Chen H, and Hoover DG (2003) Bacteriocins and their food applications, J. Food Sci., 2: 82-100.

[10] Daeschel MA, (1989) Antimicrobial substances from lactic acid bacteria for use as food preservatives, Food technol. 164167.

[11] Garneau S, Martin NI, and Vederas JC (2002) Two-peptide bacteriocins produced by lactic acid bacteria, J. Biochem. 84(5-6): 577-592.

[12] Abada EA, (2008) Isolation and characterization of a antimicrobial compound from Bacillus coagulans, Anim. Cell Syst, 1: 41-46.

[13] Lee YJ, Yu WK, Heo TR (2003) Identification and screening for antimicrobial activity against Clostridium difficile of Bifidobacterium and Lactobacillus species isolated from healthy infant, Int. J. Antimicrobial Agents., 21: $340-346$.

[14] Tagg JR, Dajani AS, and Wannamaker LW, (1976) Bacteriocins of gram positive bacteria. J. Clin. Microbiol. 40: $722-756$.

[15] Webster RE, (1991) The tol gene products and the import of macro molecules into Escherichia coli, J. Mol. Microbiol., 5: 1005-1011.

[16] James R, Penfold CN, Moore GR, and Kleanthous, (2002) Killing of E. coli cells by $\mathrm{E}$ group nuclease colicins, $J$. Biochem., 84: 381-389.

[17] Eliette RB, Sturme MHJ, Jeffery IB, 'Donnell MMO, Neville BA, Forde BM (2012) Effect of Lactobacillus salivarius Bacteriocin Abp118 on the Mouse and Pig. Intestinal Microbiota, PLOS One., 7:2, e31113.

[18] Yang E, Lihua F, Yueming J, Craig D, and Sherry F, (2012) Antimicrobial activity of bacteriocin-producing lactic acid bacteria isolated from cheeses and yogurts, App. Microbiol. Biotechnol. Exp., 2: 48.

[19] Gupta V, and Garg R (2009) Probiotics, Indian J. Med. Microbiol, 27:202-9.

[20] Alvarez-Olmos MI, and Oberhelman RA (2004) Probiotic agents and infectious diseases: a modern perspective on a traditional therapy, Cli. Inf. Diseases, 32: 1567-76.

[21] Fuller R, (1989) Probiotics in man and animals, J. App. Bacteriol., 66: 365-378.

[22] Arici M, Bilgin MB, Sagdic O, Ozdemir C (2004) Some characteristics of Lactobacillus isolates from infant faeces, Food Microbiol, 21: $19-24$.

[23] Krieg N, (1984) Bergey's Manual of Systematic Bacteriology, vol. 1,2. Baltimore, Williams and Wilkins. New York.

[24] Savadogo A, Cheik ATO, Imael HNB, and Traore AS (2004) Antimicrobial activity of lactic acid bacteria strains isolated from Burkina Faso Fermented Milk, Pak. J. Nutr., 3: 172-179.

[25] Yang R, Johnson MC, and Ray B, (1992) Novel method to extract large amount of bacteriocins from lactic acid bacteria, App. Env. Microbiol., 58: 3355-3359. 
[26] Rammelsberg M, and Radler F, (1990) Antibacterial polypeptides of Lactobacillus species, J. Appl. Bacteriol. 69: 177-184.

[27] Axellsson LT, (1993) Lactic acid bacteria: Classification and physiology. In: Lactic acid bacteria edited by Salminen S., Von Wright A., New York, Marcel Dekker, pp. 1-64.

[28] Sieber R, and Dietz UT, (1998) Lactobacillus acidophilus and yogurt in the prevention and therapy of bacterial vaginosis, Int. J. Dairy. 8:599-607.

[29] Isolauri E, Salminen S, Ouwehand AC. (2004) Microbial-gut interactions in health and disease, Probiotics Best Pract Res Clin Gastroenterol, 3:299-313.

[30] Garrity GM (1984) Bergey's manual of systematic bacteriology. vol. 2. The proteobacteria. Williams and Wilkins, New York.

[31] Vandenberg PA, (1993) Review: Lactic acid bacteria, their metabolic products and interference with microbial growth, $J$. FEMS Microbiol. 12: 221-238.

[32] Bhunia AK, Johnson MC, Ray B, and Kalchayanand N (1991) Mode of action of pediocin AcH from Pediococcus acidilactici $\mathrm{H}$ on sensitive bacterial strains, J. App. Bacteriol., 70: 25-30.

[33] Malini M, and Savitha J (2012) Detection of heat stable bacteriocin from Lactobacillus acidophilusNCIM5426 by liquid chromatography/mass spectrometry, Indian J Sci and Technol. 5: 2325-2332.
[34] Schved F, Lalazar A, Henis Y, Junen J, (1993) Purification, partial characterization and plasmid-linkage of pediocin SJ-1, a bacteriocin produced by Pediococcus acidilactici, J. Appl. Bacteriol. 74: 67-77.

[35] Gerez CL, Torino MI, Rollán G, Valdez GFd (2009) Prevention of bread mould spoilage by using lactic acid bacteria with antifungal properties, Food Control. 20: 144 148.

[36] Todorov SD, Danova ST, Reenen CAV, Meincken M, Dinkova IV, lvanova and Dicks LM, (2006) Characterization of bacteriocin HV219 produced by Lactococcus lactis subsp. Lactic HV219 isolated from human vaginal secretion, J.Basic Microbiol. 46:226-238.

[37] Rowaida k, Yasser E, Fatima D, and Sanaa O, (2009) Isolation and Partial Characterization of a Bacteriocin Produced by a Newly Isolated Bacillus megaterium 19 Strain, Pak. J. Nutr 8 (3):242-250.

[38] Moigani N, and Amirinia C (2007) Kinetics of growth and bacteriocin production in $L$ casei $\mathrm{RN} 78$ isolated from a daity sample in Iran, Int. J. Diary Scin. 2:1-12.

[39] Le MC, Hydronimus B, Bressollier P, Verneuil B, and Urdaci MC, (2000) Biochemical and genetic characterization of coagulin, a new antilisterial bacteriocin in the pediocin family of bacteriocins, produced by Bacillus coagulants I4, J. App. Environ. Microbiol., 66: 5213-5220.

[40] Rodriguez JM, (1996) Review: Antimicrobial spectrum, structure, properties and mode of action of nisin, a bacteriocin produced by Lactococcus lactis, Int. J. food Sci. Technol. 2: 61-68. 